DOI: $10.17951 / \mathrm{m} \cdot 2018.3 \cdot 67-74$

\begin{tabular}{lcr}
\hline & ANNALES & \\
& & \\
UNIVERSITATIS MARIAE CURIE-SKŁODOWSKA & \\
LOL. III & SECTIO M & 2018 \\
\hline
\end{tabular}

Marzena Cichosz

University of Wrocław

marzena.cichosz@uwr.edu.pl

ORCID ID: https://orcid.org/0000-0003-0853-742X

\title{
New Parties in Political Markets of Central and Eastern Europe in the Years 1991-2018 - a Comparative Perspective
}

\section{Introduction}

The issues surrounding new political parties constitute one of the most interesting research areas for scholars focused on party systems. This is so for several reasons. First of all, every emergence of a new player on the political scene means a shift in the structure of partisan rivalry, political and socio-political divisions - particularly if the newly born entity manages a good result in its first election. An increased support for new parties signals the opening of the political market ${ }^{1}$ and a diminished importance of entry barriers. Conversely, the lack of significant newcomers, especially in the parliamentary arena, reflects stabilisation of the party system and its corresponding socio-political structure, voters' loyalty patterns, etc.

The latter remark is central to the subject of this article, i.e. the activity of new parties in Central and Eastern Europe (CEE). In the early phases of the transformation (the first half of the 1990s), the emergence of new parties was linked directly to the democratisation process and the fact party systems were being effectively shaped anew. Many entities were born through the dismantling of umbrella organisations, as well as through splits and mergers of other

\footnotetext{
1 Defined as the space of political rivalry, including the competition among political parties.
} 
previously existing parties. Others were created by milieus hitherto uninvolved in politics, seeking to articulate their interests in the reshaped reality. Did the arena of partisan rivalry in CEE countries settle somewhat after its dynamic development in the 1990s? Are political markets - particularly their electoral and parliamentary sectors - still open to new entities and agendas in the $21^{\text {st }}$ century? These are the questions addressed in this article.

\section{Key tenets}

The article covers selected aspects of new parties' activity in the electoral and parliamentary arena - primarily, the scale of support garnered in national parliamentary elections (for lower chambers), as well as the number of parties represented in the parliaments of ten CEE states that acceded to the EU before 2010.

The category of "new parties" presents researchers with something of a challenge when it comes to definitions and their operationalisations. Parties adopt strategies that make classifying them one way or another more difficult: for instance, they change names between elections as they form and join various coalitions, simply as a "damage control" method during periods of falling out of favour with the voters. This is why any examination needs to begin with a clear-cut decision on how to categorise each type of entity. In some theoretical proposals, authors suggest a class of "genuinely new" parties - namely those characterised by a new name, organisational structures and leadership (no individuals previously involved in other political actors) ${ }^{2}$. The analysis presented here adopts a somewhat broader approach.

First of all, the author decided to select participation in election as a priority criterion. This way, parties are considered new at a stage when they register their candidates in parliamentary election for the first time. While several parties were formed during the first term of office of new parliaments as a result of their umbrella organisations breaking-up (which means they had been represented in parliaments under the previous system), that fact is not taken into account. When calculating the number of new parties, the author looked at those entities that ran in a certain election but had not run in the preceding ones.

Secondly, changes of strategies are taken into account. The deciding criterion is the age of a certain entity and number of elections it participated in, rather than the name of the committee registered for subsequent elections. As a result, parties that went through a split but retained their name (or changed it in a minor

2 A. Sikk, How Unstable? Volatility and the Genuinely New Parties in Eastern Europe, 2005, http://discovery.ucl.ac.uk/13033/1/13033.pdf [access: 12.01.2019], pp. 10-11. 
way that allowed voters to identify them as the same actor - for instance, Polish AWSP), as well as those that absorbed another entity and retained their name (for example, Czech ČSSD) are not considered new. The same goes for parties that did change their name (without going through any splits or mergers) but kept their structures and leaderships. A similar approach was adopted towards coalitions - the author considered the age of parties that constituted a given coalition, particularly that of its dominant actor. Similarly to parties, coalitions were not considered new if they changed their name in such a way that they could still be identified as the same entity (here, one can point to the example of Romanian CDR being reintroduced as CDR 2000). If a coalition was enlarged by an addition of another member, but the dominant party remained the same, it was also not accounted for as a new entity. Finally, coalitions that lost some of their components while keeping the name (or other elements key to their identity) were also not included in the "new" category.

Thirdly, parties emerging from the break-up of old organisational structures are seen as new entities if they adopted new names. In case of two or more units merging, the author considered not only whether the name distinguished the new entity from the parties that created it, but also whether the said parties ceased to exist as separate bodies.

The analysis presented here looks at the support garnered by new parties in their first elections, as well as the number and scale (as measured by voters' support) of such parties that managed to achieve representation in the lower chambers of national parliaments. In this regard, parties considered new are those that exceeded the electoral threshold or other barriers to representation for the first time. As for the criteria for assessing support, the author adopted the following classification: parties that obtained from $0.1 \%$ to $10 \%$ of votes were labelled as small, those with between $10 \%$ and $20 \%$ support were considered as mid-sized, while those with more than $20 \%$ support - as large.

For the purpose of answering the questions presented earlier, the time scope of the research (1991-2018) was divided into three decades (1990s, 2000s and 2010s).

\section{Results of the analyses}

The premise that allows one to observe the shaping of barriers in political markets across CEE is the percentage of votes garnered by new parties in their first elections. The data presented in Table 1 suggests that a certain part of the electorate has been willing to endorse new parties. Between 1991 and 2018, the average result in the first parliamentary election for such parties oscillated around $18 \%$. Interestingly, in the first decade of $21^{\text {st }}$ century, the rate decreased 
by over 2 percentage points, to $15.6 \%$, but over the following ten years it grew back up to $17.1 \%$. This would suggest a certain stabilisation of party systems in the 2000s and their decomposition in the current decade.

Table 1. Average results of new political parties in parliamentary elections in CEE* countries, 1991-2018

\begin{tabular}{|l|c|}
\hline $\begin{array}{l}\text { Average result achieved by new political parties in parliamentary elections (lower } \\
\text { chamber), 1991-2018 }\end{array}$ & $18.1 \%$ \\
\hline $\begin{array}{l}\text { Average result achieved by new political parties in parliamentary elections (lower } \\
\text { chamber), 2000-2009 }\end{array}$ & $15.6 \%$ \\
\hline $\begin{array}{l}\text { Average result achieved by new political parties in parliamentary elections (lower } \\
\text { chamber), 2011-2018 }\end{array}$ & $17.7 \%$ \\
\hline $\begin{array}{l}\text { The total number of new political parties in national parliaments (lower chamber), } \\
1991-2018\end{array}$ & 136 \\
\hline Including from 2000 to 2009 & 28 \\
\hline Including from 2010 to 2018 & 40 \\
\hline
\end{tabular}

* the author included those countries of the region that acceded to the EU before 2013.

Source: Author's own research based on data from national supervisory bodies for parliamentary elections.

While the above-mentioned observation is true for the entire region, the analysis of electoral competition in particular states reveals several different situations:

- high support for new parties in the first decade of the $21^{\text {st }}$ century and its decline in the subsequent decade (examples: Bulgaria, Lithuania, Latvia);

- a reverse image: a stabilised structure of the political market (and the correspondingly low support for new parties) in the 2000s and the change of voters' attitudes in the 2010s (examples: the Czech Republic, Poland, Romania, Slovenia, Hungary);

- a relative stability across both decades with a rare (1-2 elections out of 5-6 in total) increase in support for newcomers (examples: Estonia, Slovakia).

While the data on election results alone allows one to notice some patterns regarding the openness of political markets and the dynamics of partisan competition in each state, it is not sufficient to formulate clear-cut conclusions on the matter. Even an aggregate high support for new political parties does not necessarily need to reflect an important shift in the structure of the parliamentary scene. It may merely indicate that a high number of newcomers launched their parliamentary bids in the same election - regardless of whether any of those new actors broke through the threshold and was later represented by MPs. This is why the analysis should be complemented by a look at the number of new parties actually represented in national parliaments. 
As stated in Table 1, the period between 1991 and 2018 saw a total of 136 new political entities enter the parliaments of CEE states. Out of that number, 28 did so in the 2000s and 40 - in the 2010s. Also in this regard one may note some differences among various countries. For instance, in Latvia and Lithuania ${ }^{3}$, each election from 2000 to 2018 resulted in at least one new entity entering the lower chamber of the parliament. In all other examined countries, entry barriers for newcomers periodically increased, regardless of changes in the support for major political actors.

In order to assess the relevance of new parties in political systems, one should first and foremost examine the numbers of votes they garnered in parliamentary elections. Majority (43 out of 68 - see: Table 2) of newcomers from 2000 to 2018 can be classified as small - these are entities that received below $10 \%$ of votes. However, emerging actors also proved capable of achieving very good results: from $20 \%$ to as much as $40 \%$ of votes. Some of them, shortly after entering the political arena, became major forces: they led coalition cabinets or even formed governments on their own ${ }^{4}$. Out of nine new parties that entered national parliaments between 2000 and 2018 having garnered over $20 \%$ of votes, eight $t^{5}$ participated in governing coalitions. All nine took dominant positions in their respective systems.

Table 2. The number of new parties in lower chambers of CEE countries' parliaments, 2000-2018

\begin{tabular}{|l|c|c|c|}
\hline & $2000-2009$ & $2010-2018$ & In total: \\
\hline The number of new parties in parliaments & 28 & 40 & 68 \\
\hline including large parties (over 20\% of votes) & 5 & 4 & 9 \\
\hline including mid-sized parties (10.01-20\% of votes) & 7 & 9 & 16 \\
\hline including small parties (0.1-10\% of votes) & 16 & 27 & 43 \\
\hline
\end{tabular}

Source: Author's own research based on data from national supervisory bodies for parliamentary elections.

3 The author only considered those parties that won mandates in multi-member constituencies.

4 The case referred to here is that of Bulgarian party, Citizens for European Development of Bulgaria (GERB). In the 2009 parliamentary election, GERB collected a very impressive $39.7 \%$ of votes, which translated into $48.8 \%$ of seats. It formed a single-party government headed by Prime Minister Boyko Borisov.

5 The only exception was Zoran Janković's List - Positive Slovenia (LZJ-PS). In 2011, it received $28.5 \%$ of votes and became the largest formation in the parliament, but did not manage to form a governing coalition. 
Some mid-sized entities also managed to achieve relevance sufficient to be included in the cabinets. Out of 59 such parties that entered the parliaments between 2000 and 2018, 15 combined their emergence with an instant role as minor members of governing coalitions.

\section{Conclusions}

When one examines the number of small parties making their first attempts at elections in the period from 2000 to 2018, it is apparent that such initiatives are less frequent than during the 1990s. This may serve to confirm Margit Tavits' theory as to the negative correlation between the number of newcomers and the duration of democracy ${ }^{6}$. It certainly testifies to the creation of certain relative (related to the structure of the political market) entry barriers which hinder new players' access to the parliamentary arena. Such barriers may include a certain stabilisation in patterns of voters' behaviours and their loyalties. Despite such stability, the emerging actors still can, given favourable circumstances, achieve success in their first elections.

The reasons behind successes of genuinely new parties lie primarily in the conduct on the part of the dominant political forces. Scandals (mainly related to corruption) and unpopular policies (e.g. fiscal or social) erode the support for the incumbent parties with a history of parliamentary presence, thus opening the gap that can be filled by the newcomers ${ }^{7}$. The latter ones can also seek their chance in major changes within the political environment - such as, for example, a country's accession to the European Union or the migration crisis.

In most cases, the new entities tend to place themselves as the opposition to the mainstream. The attempt to build an image of a "higher standard", "hope", a "new opening". To use a term coined by Allan Sikk, they offer "newness as a project" the same time, in the early stages of their existence they are often plagued by a lack of recognition among voters. As a result, they adopt a more personal character by placing the name of their leader in the name of their electoral list.

In nearly all CEE countries, the increase in support for newcomers coincides with a gradual decrease in the turnout rate. Such an observation seems to validate the thesis regarding the link between the reduction of entry barriers to the parlia-

6 M. Tavits, Party System Change: Testing a Model of New Party Entry, "Party Politics" 2006, Vol. 12(1), p. 111.

7 M. Tavits, Party System in the Making: the Emergence and Success of New Parties in New Democracies, "British Journal of Political Science" 2007, Vol. 38(1), pp. 113-133.

8 A. Sikk, Newness as a Winning Formula for New Political Parties, 2012, http://discovery. ucl.ac.uk/20017/1/20017.pdf [access: 12.01.2019], pp. 16-17. 
mentary/cabinet arena and the lowered trust towards the dominant formations. However, some analysts note that the disappointment in policies implemented by new parties may lead to a further decrease in participation, as expressed by turnout rates $^{9}$. In this context, it may be a good idea to verify whether the new entities particularly those that achieve a spectacular success in their first election - are able to maintain their position in the subsequent election. Out of nine such formations that emerged between 2000 and 2009, five suffered quite severely in their second electoral tests: they recorded results that were from 10 to 20 percentage points lower than in their "debuts". Two others formed coalitions before running in their second elections. Only two (GERB in Bulgaria and SMC in Slovenia) maintained their dominant positions in the parliamentary arena. Will the disappointment with the policies of the "former" new parties open up the door to the next wave of new actors? Or will it discourage the electorate towards the idea of chasing after political novelties? The answer will be revealed when scholars examine the results of future elections in CEE countries.

\section{Bibliography}

- Pettai V., The Parliamentary Elections in Estonia, March 2003, "Electoral Studies" 2004, Vol. 23(4).

- Sikk A., How Unstable? Volatility and the Genuinely New Parties in Eastern Europe, 2005, http://discovery.ucl.ac.uk/13033/1/13033.pdf [access: 12.01.2019].

- Sikk A., Newness as a Winning Formula for New Political Parties 2012, http://discovery.ucl.ac.uk/20017/1/20017.pdf [access: 12.01.2019].

- Tavits M., Party System Change: Testing a Model of New Party Entry, "Party Politics" 2006, Vol. 12(1).

- Tavits M., Party System in the Making: the Emergence and Success of New Parties in New Democracies, "British Journal of Political Science" 2007, Vol. 38(1).

Summary: The article presents the analysis of selected aspects of the activity of new parties in ten countries of Central and Eastern Europe in the period from 1991 to 2018. The author focuses primarily on the support that the newcomers garnered in their first elections to the lower chambers of national parliaments. The election results are treated as indicators as to the openness of political markets. Furthermore, the author examines the number and scale of new entities that gained parliamentary representation.

Keywords: new parties; Central and Eastern Europe; electoral and parliamentary market

9 See, for example: V. Pettai, The Parliamentary Elections in Estonia, March 2003, "Electoral Studies" 2004, Vol. 23(4), p. 831. 
Nowe partie na rynkach politycznych w państwach Europy Środkowo-Wschodniej w latach 1991-2018 - perspektywa porównawcza

Streszczenie: Celem artykułu była analiza wybranych aspektów aktywności partii nowych na scenach politycznych dziesięciu państw Europy Środkowej i Wschodniej w latach 1991-2018. Autor skupił uwagę przede wszystkim na skali poparcia wyborczego, uzyskiwanego przez partie nowe w wyborach do izby niższej parlamentów, jako jednej z przesłanek decydujących o otwartości rynków politycznych. Analizie poddano także liczbę i wielkość (mierzoną skalą poparcia wyborczego) partii nowych, które uzyskały reprezentację parlamentarną w państwach regionu.

Słowa kluczowe: partie nowe; Europa Środkowa i Wschodnia; rynek wyborczy i parlamentarny 